\title{
A PSEUDO-DYNAMIC TEST STUDY ON A SELF-CENTERING PREFABRICATED STEEL FRAME WITH A COLUMN BASE CONNECTED BY SEMI-RIGID JOINTS
}

\author{
Yanxia Zhang $^{1 *}$, Zongyang Wang ${ }^{2}$,Wei Zhao ${ }^{2}$, Wenzhan Zhao ${ }^{2}$ and Yuanyuan Chen ${ }^{2}$ \\ 1 Associate Professor, Beijing Higher Institution Engineering Research Center of Structural Engineering and \\ New Materials, Beijing University of Civil Engineering and Architecture, Beijing 100044, China \\ 2 Postgraduate, School of Civil and Transportation Engineering, \\ Beijing University of Civil Engineering and Architecture, Beijing 100044, China \\ *(Corresponding author: E-mail: zhangyanxia@bucea.edu.cn)
}

Received: 4 September 2015; Revised: 10 September 2015; Accepted: 19 September 2016

\begin{abstract}
Self-centering steel frame structures are advantageous in that they can control structural damage, reduce or eliminate residual deformation, and are easy to repair after strong earthquakes. A self-centering prefabricated steel frame with a column base connected by semi-rigid joints (SPSF-SRJ) is proposed in the present study. The goal is to address the problem of excessive plasticity that a self-centering prefabricated frame with a column base connected by rigid joints exhibits. In addition, a pseudo-dynamic test is performed on the sub-structure of the proposed system to investigate and discuss the seismic performance of the system, which is then compared with the seismic performance of a self-centering prefabricated steel frame with a column base connected by rigid joints (SPSF-RJ). The test results show that the proposed performance-based design goal can be realized in the SPSF-SRJ. The semi-rigid joints effectively protect the column base and eliminate or reduce the damage to the columns; after an earthquake, only the steel beams require repairs, which significantly reduces the post-earthquake repair cost.
\end{abstract}

Keywords: Self-centering prefabricated steel frame, Column base connected by Semi-rigid joints, Pseudo-dynamic test, Performance-based design goal, Gap opening, Plastic strain

DOI:10.18057/IJASC.2016.12.3.5

\section{INTRODUCTION}

Self-centering steel frame structures are advantageous in that they can control structural damage, reduce or eliminate residual deformation, and are easy to repair after strong earthquakes. Rojas and Ricles et al. $[1,2,3]$ studied friction-type self-centering steel frames. Lin et al. [4, 5] conducted a pseudo-dynamic test study on self-centering steel frames. Zhang et al. [6, 7] conducted experimental and theoretical studies on self-centering structural systems that dissipated energy through web friction devices and proposed a self-centering prefabricated steel frame system. The existing connection and plane frame tests showed that the system proposed by Zhang et al. [6, 7]. exhibited the aforementioned advantages of self-centering steel frames; in addition, with this proposed system, post-tensioned(PT) strands could be tensioned on the ground of the construction site instead of being tensioned above the ground, and the beam-column connections only need to be connected using the mixed bolting-welding method, which is used to connect conventional beam-column connections. However, Zhang et al. [6,7] also discovered that plastic deformation of the bottom columns of the self-centering prefabricated steel frame still occurred under medium-earthquake or large-earthquake conditions. Hoseok et al. [8, 9] proposed the use of prestressed column connectors at the column base of a self-centering frame; their finite element simulation and experimental study showed that the column base of the system could return to their original position automatically; in addition, the energy-dissipation device installed at the column base prevented plastic deformation from occurring; however, due to the gravitational effect, the vertical anchor cable structure was complicated and achieved self-centering abruptly and thus, was 
not easily accepted by designers. Based on the research results of our research group as well as research groups in China and other countries, an self-centering prefabricated steel frame with a column base connected by semi-rigid joints (referred to as SPSF-SRJ hereinafter) is proposed in the present study with the goal of addressing the problem of excessive plasticity that a self-centering frame with a column base connected by rigid joints exhibits, and performance-based design goal of "no gap opening and no damage occurs during frequent earthquakes; gap openings are formed to dissipate energy, and no damage occurs to the main structure during design earthquakes; only extremely small structural damage occurs, and the structure can still normally operate during rare and extremely rare earthquakes (8.5 rare earthquake) is put forward. In addition, a pseudo-dynamic test is performed on the sub-structure of the SPSF-SRJ to investigate and discuss the seismic performance of the SPSF-SRJ, which is then compared with the seismic performance of an SPSF with a column base connected by rigid joints (referred to as SPSF-RJ hereinafter).

\section{STRUCTURE OF A TYPICAL CONNECTION OF A SELF-CENTERING PREFABRICATED STEEL FRAME}

A typical beam-column connection of a prefabricated prestressed steel frame system has a joint structure that connects a frame column and a prestressed steel beam (Figure 1). A prestressed steel beam consists of a middle beam portion, two short beam portions, a strengthening device, a connecting device, and an energy-dissipation device. The connecting device consists of a vertical plate and a prestressed strand. The strengthening device consists of a transverse stiffener and a longitudinal stiffener that are welded onto the short beam web. The energy-dissipation device uses a web friction damper and contains steel splice plates, which are positioned on the two sides of the web of the middle beam portion, and friction bolts for energy dissipation. Long holes are created at locations on the web of the middle beam portion that correspond to the friction bolts. A brass plate is sandwiched between the web of the middle beam portion and the splice plate to ensure a stable friction coefficient. Stiffeners are installed at the location where the steel frame column levels with the flange of the short beam segment.

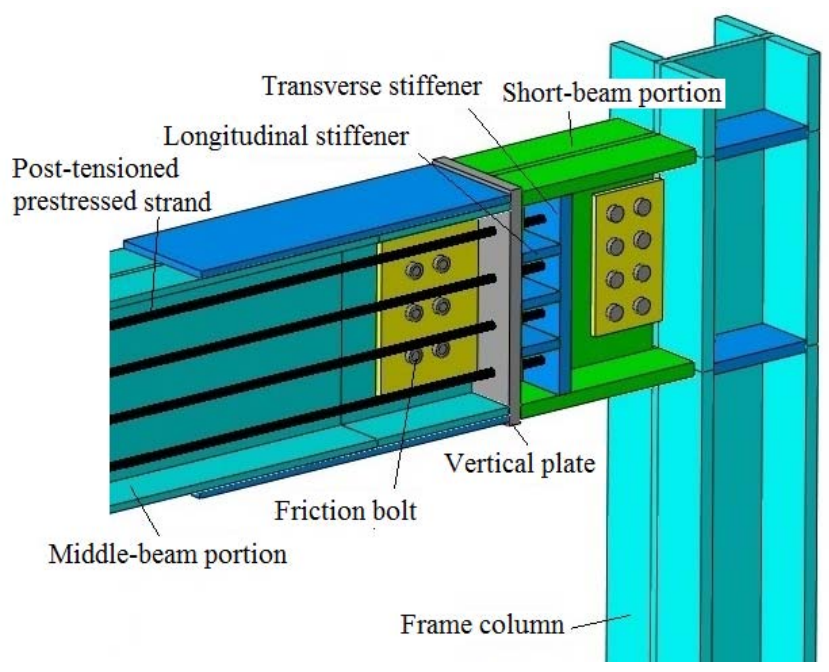

Figure 1. Typical Beam-column Connection of a Self-centering Prefabricated Steel Frame System 


\section{PROTOTYPE STRUCTURE AND TEST MODEL}

\subsection{Prototype Structure}

Based on the proposed performance-based design goal, studies on self-centering connection structures conducted by Georgios et al. $[10,11,12,13]$, characteristics of self-centering prefabricated steel frames, related design standards of other countries [14,15,16,17], and the Code for Seismic Design of Buildings of China [18], a 4-story SPSF-SRJ prototype structure that uses a web friction damper for energy dissipation was designed. Figure 2 shows the structural plane. Each span of the structural plane is $8 \mathrm{~m}$; the first story is $3.8 \mathrm{~m}$ high, and the second to fourth stories are each $3.6 \mathrm{~m}$ high. The beam-column connections of the frame in the peripheral blue area are prefabricated prestressed steel frame. Box-section frame columns (section dimensions: $\square 400 \mathrm{~mm} \times 400 \mathrm{~mm} \times 34 \mathrm{~mm}$ ) were used in the present study. Each frame beam had section dimensions of $\mathrm{H} 588 \mathrm{~mm} \times 300 \mathrm{~mm} \times 12 \mathrm{~mm} \times 20 \mathrm{~mm}$. All other beam-column connections were articulated. Each column had dimensions of $\square 400 \mathrm{~mm} \times 400 \mathrm{~mm} \times 30 \mathrm{~mm}$. Each beam had dimensions of $\mathrm{H} 588 \mathrm{~mm} \times 300 \mathrm{~mm} \times 12 \mathrm{~mm} \times 20 \mathrm{~mm}$. M24 bolts were used as the bolts for energy dissipation and as the beam-column connecting bolts; $1 \times 19$ steel strands with a nominal area of $312.9 \mathrm{~mm}^{2}$ were used.

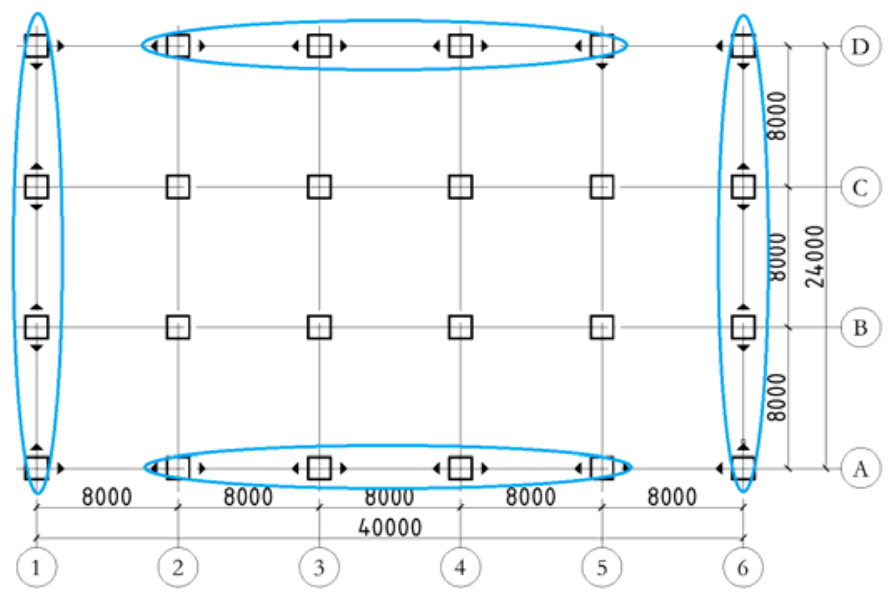

Figure 2. Plan Schematic of Prototype Structure

\subsection{Test Model}

The pseudo-dynamic test method for sub-structures was used in the present study. The SPSF in the middle of the bottom story of the prototype structure was selected as the sub-structure for testing. Considering the test conditions, the prototype structure was scaled down by $75 \%$. The frame columns of the test model were under the same axial compression ratio as those of the prototype structure. In addition, the test model had the same ratio of imminent gap opening moment to the plastic limit moment of the section of the long beam as the prototype model. Figure 3 shows the detailed dimensions of the test model. The test model had a story height of $3.15 \mathrm{~m}$ and a span of 6 $\mathrm{m}$. The model had H300mm $\times 300 \mathrm{~mm} \times 20 \mathrm{~mm} \times 30 \mathrm{~mm}$ frame column, H450mm $\times 250 \mathrm{~mm} \times$ $14 \mathrm{~mm} \times 16 \mathrm{~mm}$ middle beam segment,H482 mm $\times 250 \mathrm{~mm} \times 14 \mathrm{~mm} \times 30 \mathrm{~mm}$ short beam segment. Each column stiffener had a thickness of $30 \mathrm{~mm}$. The transverse stiffener and longitudinal stiffener of the short beam thickness is $30 \mathrm{~mm}$ and $20 \mathrm{~mm}$, respectively. The vertical plate had a thickness of 30 $\mathrm{mm}$. The reinforcing plate of the flange of the middle beam segment had a thickness of $16 \mathrm{~mm}$ and a length of $800 \mathrm{~mm}$. Eight grade $10.9 \mathrm{M} 24$ bolts were used as the bolts for the energy dissipation. Eight grade 10.9 M20 bolts were used as the beam-column connecting bolts. Eight $1 \times 19$ steel strands were used as the PT strands; an initial PT force value of $0.25 T_{\mathrm{u}}$ was selected for a single 
prestressed strand.

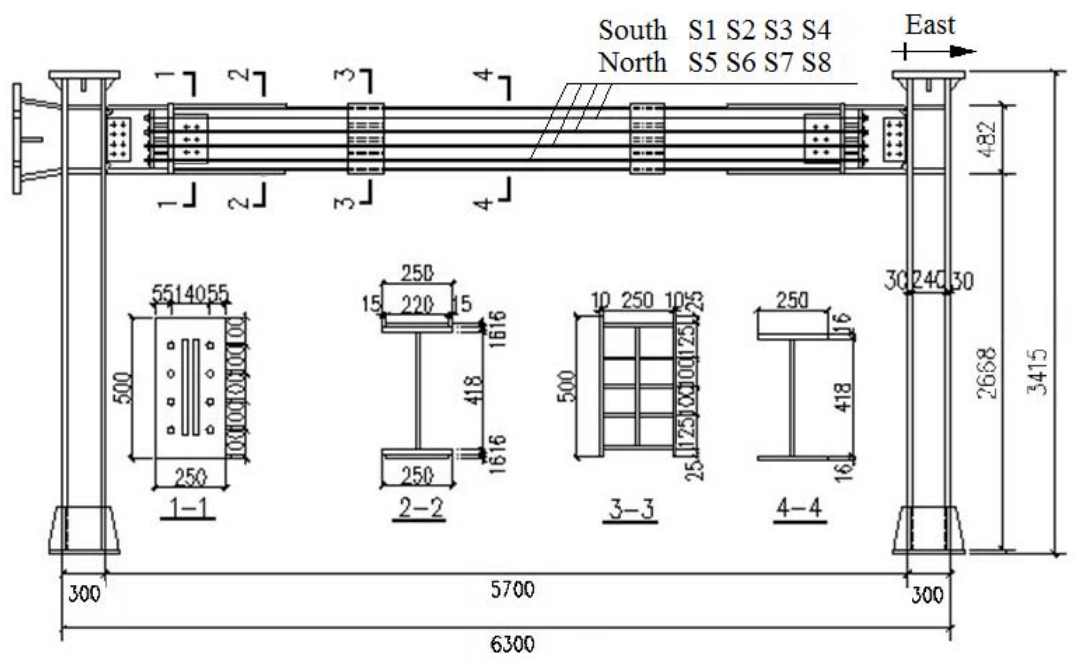

Figure 3. Detailed Dimensions of the Test Model

（Side strands:S1、S4、S5、S8, Middle strands:S2、S3、S6、S7）

\subsection{Material Properties}

Five sectional specimen thicknesses were used $-14 \mathrm{~mm}, 16 \mathrm{~mm}, 18 \mathrm{~mm}, 20 \mathrm{~mm}$, and $30 \mathrm{~mm}$. The steel product grade was Q345B. The mechanical properties of the specimen materials were tested and Table 1 lists the test results of the mechanical properties of the specimen materials. Table 2 lists the test results of the properties of the prestressed strand. Grade 10.9 bolts were used. The friction coefficient between the brass plate and steel plate was tested to be 0.34-0.38.

Table 1. The Mechanical Properties of the Specimen Materials

\begin{tabular}{ccccc}
\hline $\begin{array}{c}\text { Thick } \\
(\mathrm{mm})\end{array}$ & $\begin{array}{c}\text { Yield } \\
\text { strength } \\
\left(\mathrm{N} / \mathrm{mm}^{2}\right)\end{array}$ & $\begin{array}{c}\text { Ultimate strength } \\
\left(\mathrm{N} / \mathrm{mm}^{2}\right)\end{array}$ & $\begin{array}{c}\text { Elastic modulus } \\
\left(\times 10^{5} \mathrm{~N} / \mathrm{mm}^{2}\right)\end{array}$ & Percent elongation at fracture \\
\hline 14 & 384 & 561 & 2.15 & 27.0 \\
16 & 392 & 555 & 2.06 & 23.3 \\
18 & 381 & 555 & 2.22 & 25.3 \\
20 & 384 & 550 & 2.09 & 25.7 \\
22 & 388 & 574 & 2.09 & 26.8 \\
30 & 350 & 505 & 2.07 & 26.5 \\
\hline
\end{tabular}

Table 2. Prestressed Strand Material Properties

\begin{tabular}{ccccc}
\hline Strand & Specimen & $\begin{array}{c}\text { Yield } \\
\text { strength } \\
(\mathrm{kN})\end{array}$ & $\begin{array}{c}\text { Ultimate } \\
\text { strength } \\
(\mathrm{kN})\end{array}$ & $\begin{array}{c}\text { Elastic modulus } \\
\left(\times 10^{5} \mathrm{~N} / \mathrm{mm}^{2}\right)\end{array}$ \\
\hline \multirow{3}{*}{$1 \times 19$} & 1 & 1728.3 & 1894.5 & 2.03 \\
& 2 & 1727.1 & 1895.8 & 2.05 \\
& 3 & 1732.8 & 1875.4 & 2.00 \\
& Average value & 1729 & 1889 & 2.03 \\
\hline
\end{tabular}




\section{TEST SCHEME}

\subsection{Loading Device and Input Parameters}

The multi-story structural remote cooperative pseudo-dynamic test platform (NetSLab_MSBSM1.0.0) developed by Hunan University was used in the present study. Due to the relatively large span of the SPSF-SRJ and the limited laboratory conditions, the axial pressure on the top of each column was applied through vertical prestressed strands, and $1 \times 19$ steel strands with a nominal diameter of $21.8 \mathrm{~mm}$ were still used for the test. Four prestressed strands were placed on each side of the structure. A single prestressed strand has a PT force of $189 \mathrm{kN}$. The lateral force was applied through a 200t actuator. Figures 4 and 5 show the schematics and a photograph of the loading device used in the test, respectively. Earthquake ground motions were used as inputs into the test platform structure to calculate the displacement, which was then exerted through the actuator. It was necessary to input the floor quality and theoretical inter-story restoring force model into the test platform to calculate the sub-structure. The floor quality, which was an input into the platform structure, was based on the floor quality of the prototype structure and the similarity relation between the test structure and prototype structure. The double-flag model provided by our research group was used as the theoretical inter-story restoring force model. The quality of each floor and the stiffness parameter were obtained through a finite element analysis of the planar frame. The column base connected by semi-rigid joints was realized by eliminating the pressure beam on the top of the column base and reducing the rotational stiffness of the column base (Figure 4).

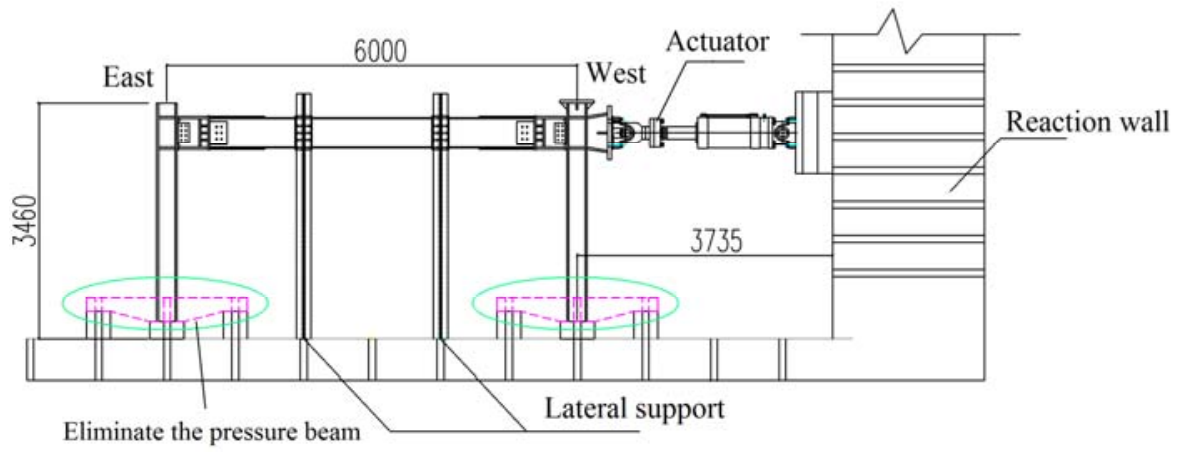

Figure 4.Test Setup

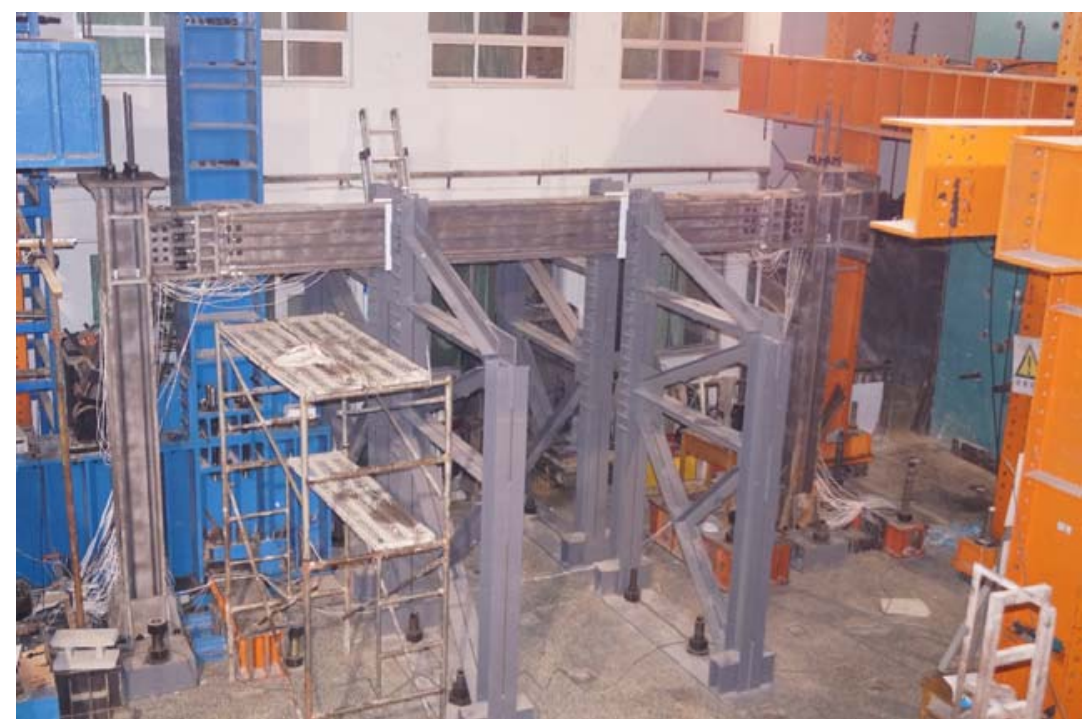

Figure 5. Photograph of the Loading Device used during the Test 


\subsection{Selection of Earthquake Ground Motions}

Three earthquake ground motions, Taft, LOS000, and EL-Centro, were selected for the test. Figures 6-8 show the time history curves of the three selected earthquake ground motions. The peak ground acceleration (PGA) of the three earthquake ground motions were adjusted to $0.4 g$. In addition, the time history curves were converted to acceleration response spectra using the SeismoSignal software (Figure 9). The first period of the test model was 1.23s. Each response spectrum curve essentially coincided with the standard response spectrum curve at the first period.

Seismic acceleration records with $\mathrm{PGA}=0.07 g, 0.2 g, 0.4 g$, and $0.51 g$ were inputs in the test according to earthquakes with four different levels: 8.0-degree frequent earthquake, design earthquake, rare earthquake, and 8.5-degree rare earthquake, according to Chinese Code for Seismic Design of Buildings(GB 50011-2010,2010). The three earthquake ground motions all had a time step of $0.01 \mathrm{~s}$. Considering the reduced scale, the time step of each earthquake ground motion was adjusted to $0.0086 \mathrm{~s}$. A damping ratio of 0.05 was also selected. Before inputting the earthquake ground motions, preloading was performed to measure the actual stiffness of the test sub-structure, which was used as the basis for the subsequent calculation.

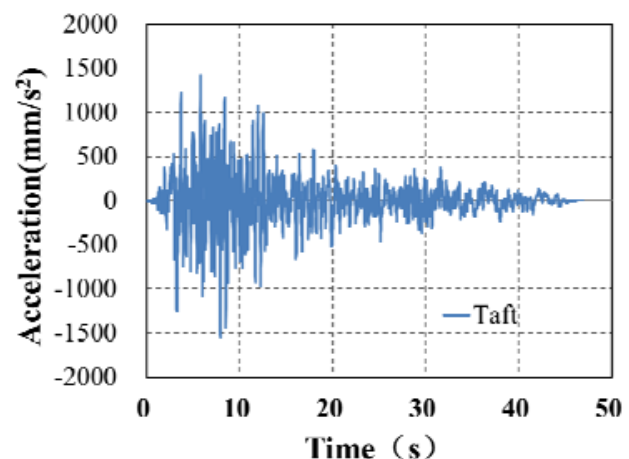

Figure 6. Taft Ground Motion Record

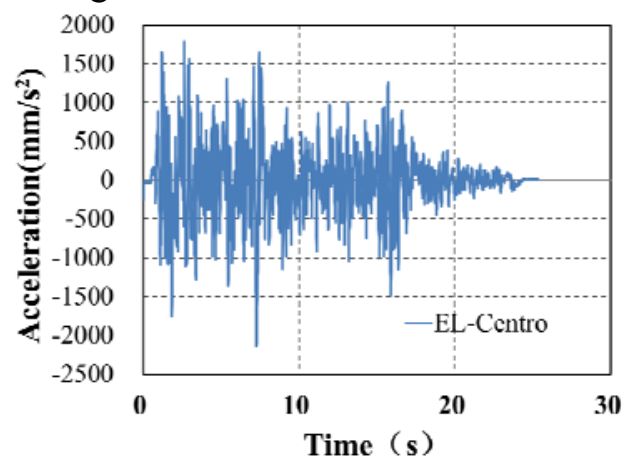

Figure 8. EL-Centro Ground Motion Record

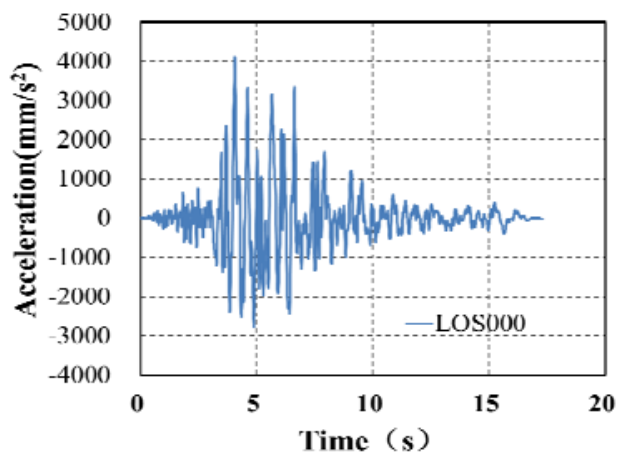

Figure 7. LOS000 Ground Motion Record

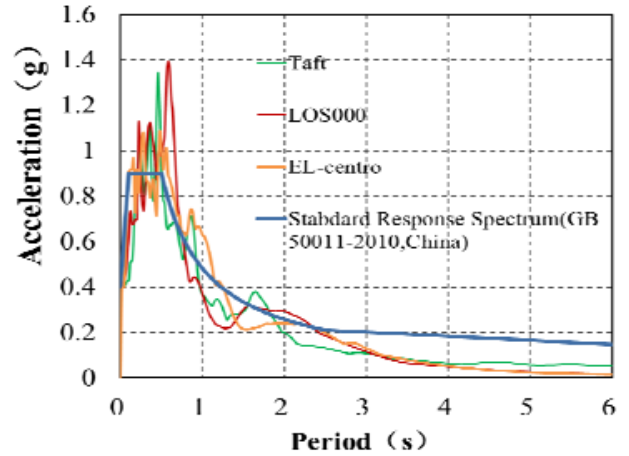

Figure 9. Acceleration Response Spectrum

\subsection{Measurement Content}

(1) Measurement of the load: the change in the load during the test process was measured using the sensor that was installed in the actuator.

(2) Measurement of the PT force of the prestressed strands: the changes in the PT force of the prestressed strands were recorded in real time using a 50t pressure load sensor.

(3) Measurement of the displacements: as shown in Figure 10, eight linear displacement potentiometers were placed at the gap opening of each connection to measure the width of the gap opening of each connection; the changes in the displacements were measured using the sensor that 
was installed in the actuator; a displacement meter with a measurement range of $150 \mathrm{~mm}$ was placed on top of the column on the east side to record the displacement of the top of the column; one displacement meter with a measurement range of $50 \mathrm{~mm}$ was placed on the east side of the column base, and another displacement meter with a measurement range of $50 \mathrm{~mm}$ was placed on the west side of the column base to record the horizontal slippage of the column base.

(4) Measurement of the strain: strain gauges were installed on the flange of the short beam, flange of the long beam, flange of the column base, web of the column base, flange in the connection region, and web in the connection region in the transverse and longitudinal directions to measure the change in the strain at each location during the loading process.

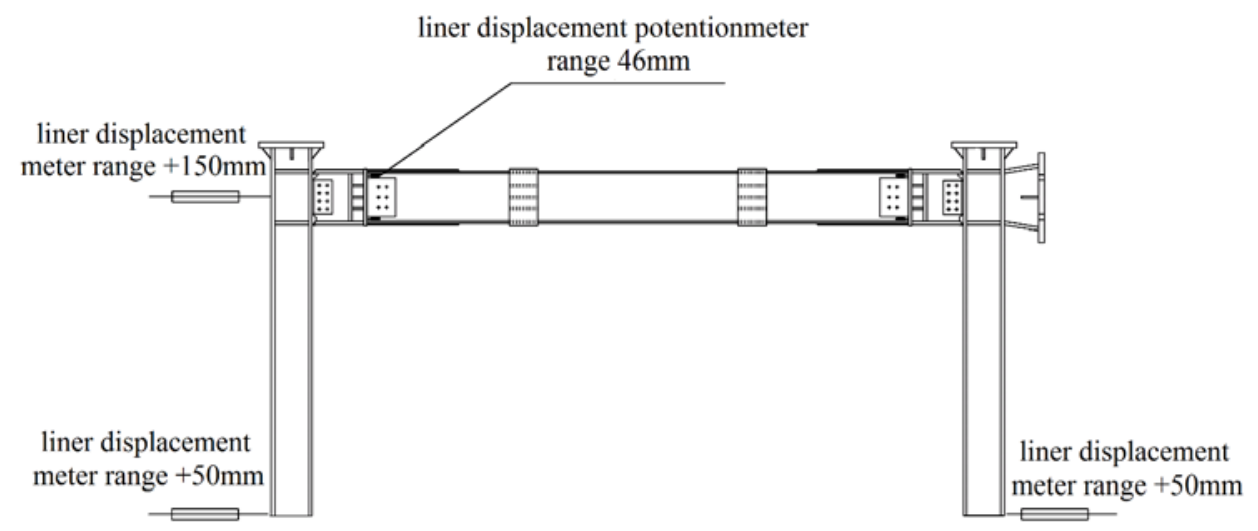

Figure 10. Arrangement of Displacement Meter

\section{ANALYSIS OF THE TEST RESULTS}

The dynamic characteristics of the SPSF-SRJ were studied by analyzing the displacement response of the structure, the gap openings of the connections, shear force of the base, hysteretic behavior, stiffness, PT force, and strain.

\subsection{Deformation and Drift Response}

Figure 11-12 shows a photograph of the lateral displacement of the column under the action of the EL-Centro ground motion $(\mathrm{PGA}=0.4 \mathrm{~g}$ and $\mathrm{PGA}=0.51 \mathrm{~g})$. The actuator acts on the column on the west side, which means that the east side and west side of the structure have asymmetrical stiffness; therefore, the displacement on the west side is often slightly greater than that on the east side. In the present study, the structural displacement response analysis is performed using the non-loaded east side of the structure as an example. The structural displacement-time histories under the actions of the EL-Centro ground motion of different earthquake levels are shown in Figures 13 where all displacement histories return to zero at the end of the tests, demonstrating self-centering behavior.

Table 3 lists the maximum displacement responses of the east side of the structure and the inter-story drifts. Under the action of the EL-Centro ground motion of PGA $=0.07 \mathrm{~g}$, the SPSF-SRJ exhibits the maximum displacement response $(18.94 \mathrm{~mm})$, which is slightly larger than that of the SPSF-RJ $(17.21 \mathrm{~mm})$, because the lateral rigidity of SPSF-SRJ is usually less than that of SPSF-RJ. The SPSF-SRJ and SPSF-RJ have maximum inter-story drifts of $1 / 218$ and 1/166, respectively; even though these maximum inter-story drifts exceed the elastic inter-story drifts limit defined in the Code for seismic design of buildings (1/250), the frames can essentially return to their original positions after an earthquake. Similarly, duo to the rigidity reason, the displacement of SPSF-SRJ $(40.5 \mathrm{~mm})$ is greater than that of SPSF-RJ $(30.65 \mathrm{~mm})$ under the action of the EL-Centro ground motion of $\mathrm{PGA}=0.2 \mathrm{~g}$. 
The maximum displacement response of SPSF-SRJ under the action of the three ground motions of $\mathrm{PGA}=0.4 \mathrm{~g}$ is $77.01 \mathrm{~mm}$, greater than that of SPSF-RJ $(62.2 \mathrm{~mm})$. The maximum inter-story drifts under the action of the Taft, LOS000 and EL-Centro ground motions of PGA=0.4g are 1/63, 1/57, and $1 / 41$, respectively. The displacement response under the action of the EL-Centro ground motion is the largest and already exceeds the elastic inter-story drift limit of a frame defined in the Code for seismic design of buildings (1/50), but the frame can still return to its original position after an earthquake. Under the action of the Taft, LOS000, and EL-Centro ground motion of PGA $=0.51 \mathrm{~g}$, the maximum displacement responses are $55.43 \mathrm{~mm}, 64.32 \mathrm{~mm}$, and $89.71 \mathrm{~mm}$, respectively, still exhibit the maximum displacement response than that of SPSF-RJ.

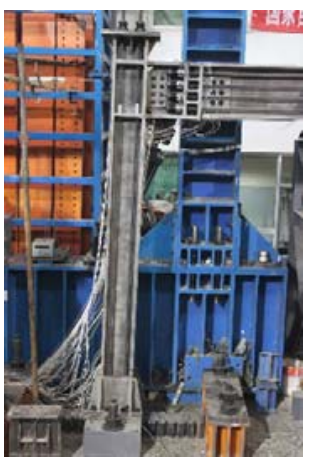

a) East column Inter-story drift at $1 / 41$

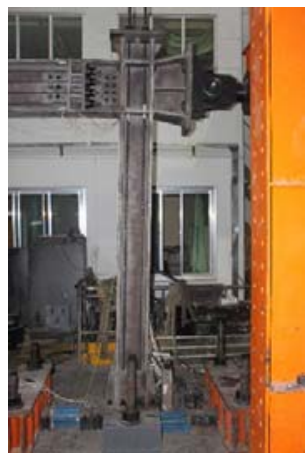

b) West column Inter-story drift at $1 / 41$

Figure 11. Column Lateral Displacement Photographs from El-Centro $(\mathrm{PGA}=0.4 \mathrm{~g})$

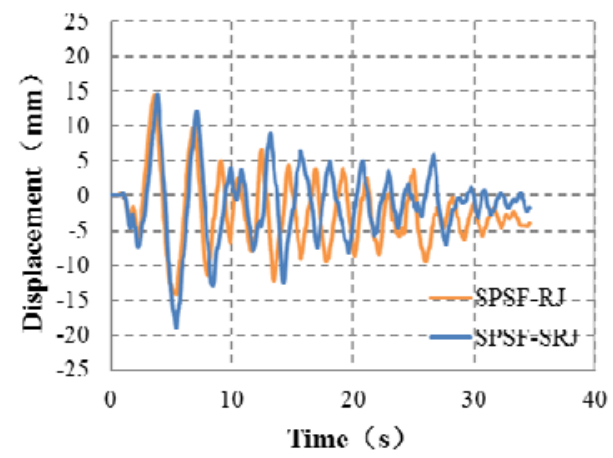

a) $0.07 \mathrm{~g}$

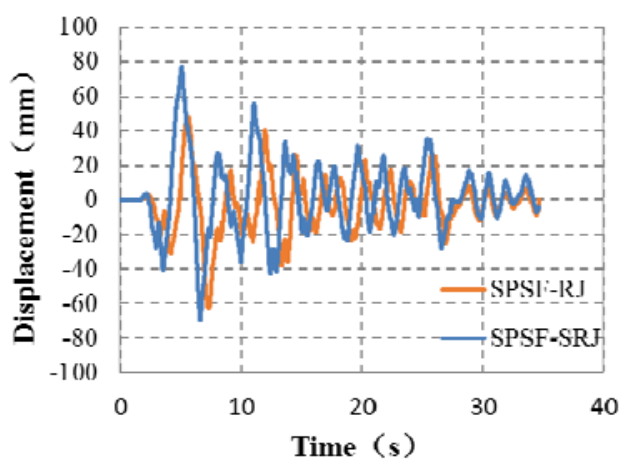

c) $0.4 \mathrm{~g}$

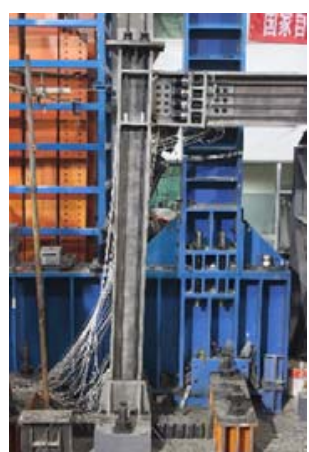

a) East column

Inter-story drift at $1 / 35$

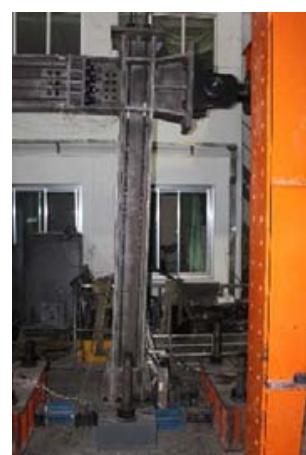

b) West column Inter-story drift at $1 / 32$
Figure 12. Column Lateral Displacement Photographs from El-Centro $(\mathrm{PGA}=0.51 \mathrm{~g})$

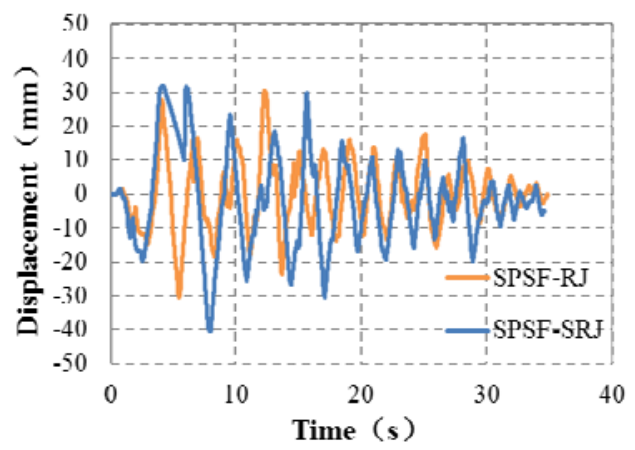

b) $0.2 \mathrm{~g}$

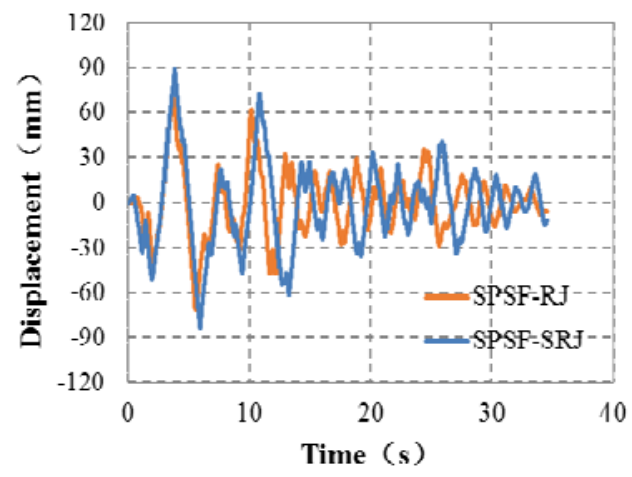

d) $0.51 \mathrm{~g}$

Figure 13. Lateral Displacement Time History from EL-Centro at East Side 
Table 3. Displacement Responses and Inter-Story Drifts of SPSF-RJ and SPSF-SRJ

\begin{tabular}{cccccccccc}
\hline \multirow{2}{*}{ Seismic events } & \multicolumn{3}{c}{ Displacement (mm) } & \multicolumn{4}{c}{ Inter-story drifts (rad) } \\
& & $0.07 \mathrm{~g}$ & $0.2 \mathrm{~g}$ & $0.4 \mathrm{~g}$ & $0.51 \mathrm{~g}$ & $0.07 \mathrm{~g}$ & $0.2 \mathrm{~g}$ & $0.4 \mathrm{~g}$ & $0.51 \mathrm{~g}$ \\
\hline \multirow{3}{*}{ SPSF-RJ } & Taft & 8.28 & 20.28 & 33.24 & 43.73 & $1 / 380$ & $1 / 155$ & $1 / 95$ & $1 / 78$ \\
& LOS000 & 12.65 & 24.67 & 44.02 & 53.91 & $1 / 249$ & $1 / 128$ & $1 / 72$ & $1 / 58$ \\
& EL-Centro & 17.21 & 30.65 & 62.2 & 71.53 & $1 / 218$ & $1 / 103$ & $1 / 50$ & $1 / 44$ \\
& Taft & 8.24 & 20.95 & 49.86 & 55.43 & $1 / 382$ & $1 / 150$ & $1 / 63$ & $1 / 57$ \\
SPSF-SRJ & LOS000 & 11.63 & 27.92 & 55.19 & 64.32 & $1 / 271$ & $1 / 113$ & $1 / 57$ & $1 / 49$ \\
& EL-Centro & 18.94 & 40.5 & 77.01 & 89.71 & $1 / 166$ & $1 / 78$ & $1 / 41$ & $1 / 35$ \\
\hline
\end{tabular}

\subsection{Connections Gap Opening}

Figure $14 \sim 16$ give photographs of the connections under the action of the EL-Centro ground motion of different earthquake levels and Tables 4 and 5 list the gap opening rotation $\left(\theta_{r}\right)$ and residual rotation $\left(\theta_{\text {res }}\right)$ of the connections on the east and west sides. Under the action of ground motion of $\mathrm{PGA}=0.07 \mathrm{~g}$, the connections gap openings are not formed. Under the action of ground motions of $\mathrm{PGA}=0.2 \mathrm{~g}, 0.4 \mathrm{~g}, 0.51 \mathrm{~g}$, the maximum gap opening rotations of the connections of the SPSF-SRJ are close to or slightly greater than that of the SPSF-RJ due to the rotation of column base of SPSF-SRJ. The maximum residual rotation (obtained by dividing the difference in residual displacements of adjacent floors by the story height) of the connections of the SPSF-SRJ is only $0.13 \%$, which indicate the frame can return to its original position after an earthquake.

It can be observed from the above analysis that the connections do not open under the action of a frequent earthquake. Under the action of a design earthquake or a more intense earthquake, the connections begin to open; in addition, the gap opening rotation of the connections of the SPSF-SRJ are greater than those of the SPSF-RJ, and the residual rotation are extremely small; furthermore, The test results prove that the connections of the SPSF-SRJ exhibit a relatively good opening/closing mechanism and have a good self-centering capability, similar to the SPSF-RJ.

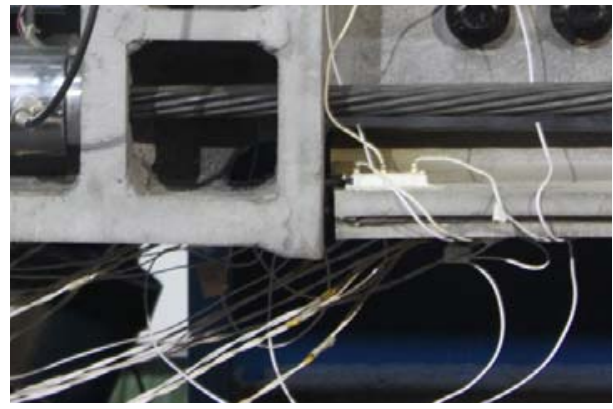

a) The gap opening width of the connection on the east side: $3.97 \mathrm{~mm}$; gap opening rotation: $0.91 \%$

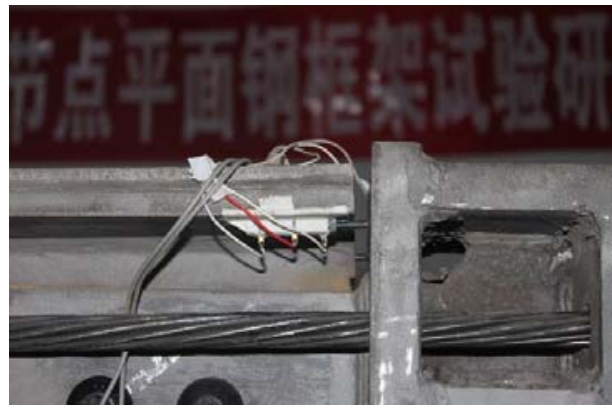

b) The gap opening width of the connection on the west side: $4.52 \mathrm{~mm}$; gap opening rotation: $1.04 \%$

Figure 14. Connections photograph from EL-Centro(PGA=0.2g) 


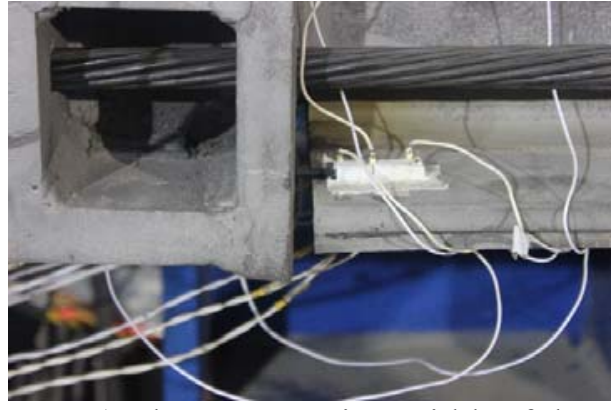

a) The gap opening width of the connection on the east side: $9.96 \mathrm{~mm}$; gap opening rotation: $2.29 \%$

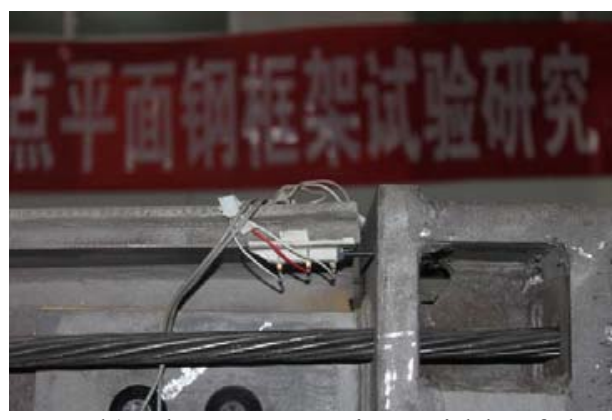

b) The gap opening width of the connection on the west side: $11.79 \mathrm{~mm}$; gap opening rotation: $2.72 \%$

Figure 15. Connections Photograph from EL-Centro $(\mathrm{PGA}=0.4 \mathrm{~g}$ )

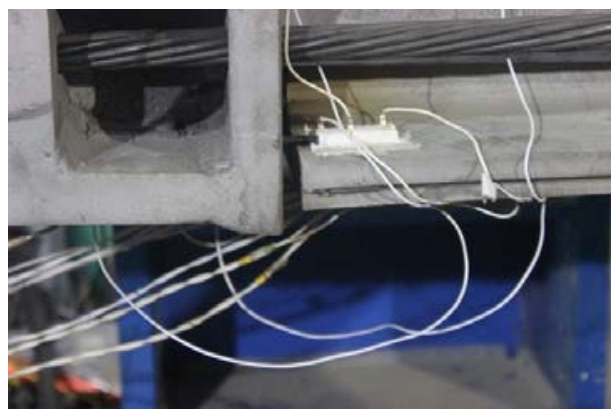

a) The gap opening width of the connection on the east side: $13.37 \mathrm{~mm}$; gap opening rotation: $3.08 \%$

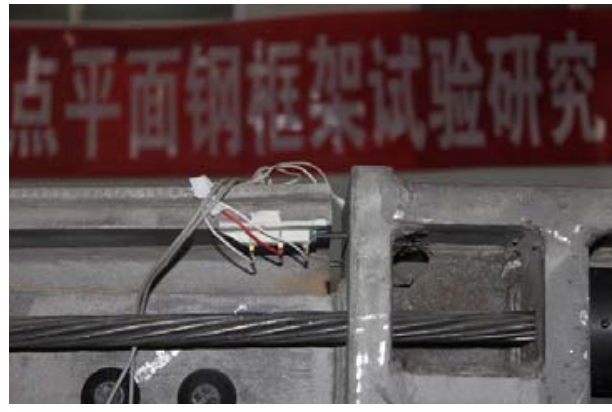

b) The gap opening width of the connection on the west side: $14.28 \mathrm{~mm}$; gap opening rotation: $3.29 \%$

Figure 16. Connections Photograph from EL-Centro $(\mathrm{PGA}=0.51 \mathrm{~g})$

Table 4. Gap Opening Rotation and Residual Rotation of the Connections on the East Side

\begin{tabular}{cccccccc}
\hline \multirow{2}{*}{ Seismic events } & \multicolumn{3}{c}{ Gap opening rotation (rad) } & \multicolumn{3}{c}{ Residual rotation (rad) } \\
& & $0.2 \mathrm{~g}$ & $0.4 \mathrm{~g}$ & $0.51 \mathrm{~g}$ & $0.2 \mathrm{~g}$ & $0.4 \mathrm{~g}$ & $0.51 \mathrm{~g}$ \\
\hline \multirow{5}{*}{ SPSF-RJ } & Taft & $0.26 \%$ & $0.81 \%$ & $1.04 \%$ & $0.02 \%$ & $0.18 \%$ & $0.06 \%$ \\
& LOS000 & $0.41 \%$ & $0.78 \%$ & $1.53 \%$ & $0.03 \%$ & $0.06 \%$ & $0.11 \%$ \\
& EL-Centro & $0.63 \%$ & $1.92 \%$ & $2.54 \%$ & $0.02 \%$ & $0.04 \%$ & $0.24 \%$ \\
& Taft & $0.29 \%$ & $1.27 \%$ & $1.58 \%$ & $0.00 \%$ & $0.03 \%$ & $0.13 \%$ \\
SPSF-SRJ & LOS000 & $0.42 \%$ & $1.12 \%$ & $1.68 \%$ & $0.02 \%$ & $0.00 \%$ & $0.00 \%$ \\
& EL-Centro & $0.91 \%$ & $2.29 \%$ & $3.08 \%$ & $0.05 \%$ & $0.02 \%$ & $0.08 \%$ \\
\hline
\end{tabular}

Table 5. Gap Opening Rotation and Residual Rotation of the Connections on the West Side

\begin{tabular}{cccccccc}
\hline \multirow{2}{*}{ Seismic events } & \multicolumn{2}{c}{ Gap opening rotation (rad) } & \multicolumn{3}{c}{ Residual rotation (rad) } \\
& & $0.2 \mathrm{~g}$ & $0.4 \mathrm{~g}$ & $0.51 \mathrm{~g}$ & $0.2 \mathrm{~g}$ & $0.4 \mathrm{~g}$ & $0.51 \mathrm{~g}$ \\
\hline \multirow{3}{*}{ SPSF-RJ } & Taft & $0.41 \%$ & $1.06 \%$ & $1.65 \%$ & $0.03 \%$ & $0.01 \%$ & $0.02 \%$ \\
& LOS000 & $0.65 \%$ & $1.23 \%$ & $2.00 \%$ & $0.07 \%$ & $0.13 \%$ & $0.31 \%$ \\
& EL-Centro & $0.89 \%$ & $2.78 \%$ & $3.23 \%$ & $0.03 \%$ & $0.09 \%$ & $0.07 \%$ \\
\multirow{5}{*}{ SPSF-SRJ } & Taft & $0.65 \%$ & $1.23 \%$ & $1.62 \%$ & $0.03 \%$ & $0.06 \%$ & $0.02 \%$ \\
& LOS000 & $0.64 \%$ & $1.19 \%$ & $1.68 \%$ & $0.00 \%$ & $0.01 \%$ & $0.00 \%$ \\
& EL-Centro & $1.04 \%$ & $2.72 \%$ & $3.29 \%$ & $0.08 \%$ & $0.01 \%$ & $0.03 \%$ \\
\hline
\end{tabular}




\subsection{Base Shear Force}

Figure 17 shows the base shear force-time histories of the SPSF-SRJ and SPSF-RJ under the action of the EL-Centro ground motion of different earthquake levels. Under the action of PGA $=0.07 \mathrm{~g}$, the maximum base shear force of SPSF-SRJ is close to that of SPSF-RJ. Under the action of $\mathrm{PGA}=0.2 \mathrm{~g}, 0.4 \mathrm{~g}, 0.51 \mathrm{~g}$, The maximum base shear forces of the SPSF-SRJ are almost less than those of the SPSF-RJ, still because the rigidity of SPSF-SRJ is usually less than that of SPSF-RJ

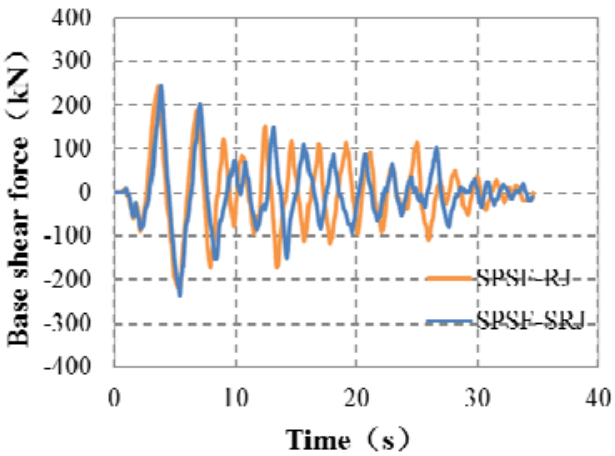

a)PGA $=0.07 \mathrm{~g}$

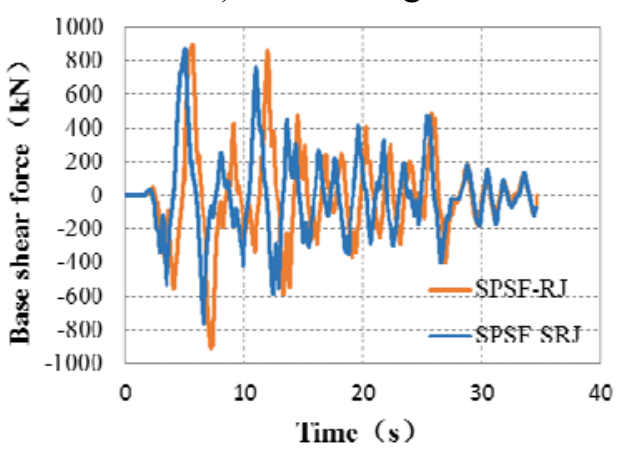

c) $\mathrm{PGA}=0.4 \mathrm{~g}$

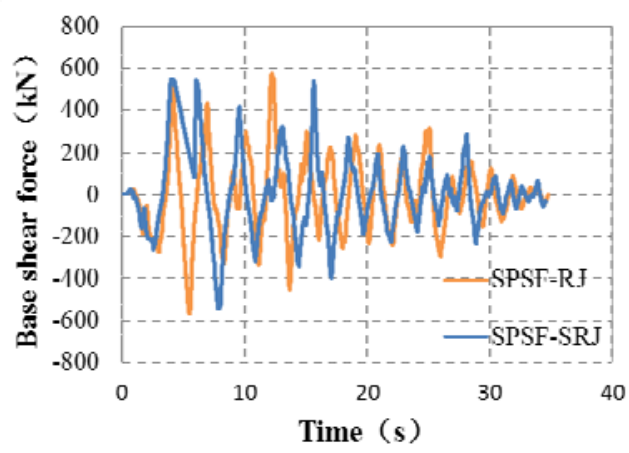

b)PGA $=0.2 \mathrm{~g}$

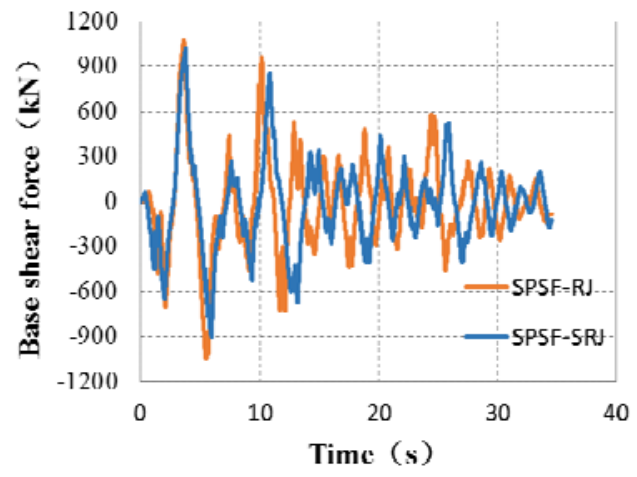

d)PGA $=0.51 \mathrm{~g}$

Figure 17. Base Shear Force-time History from EL-Centro

\subsection{Hysteretic Behavior}

Figure 18 gives the base shear force-displacement hysteretic curves of the SPSF-SRJ and SPSF-RJ under the action of the EL-Centro ground motion of different earthquake levels. In the present study, the hysteretic behavior of the SPSF-SRJ and SPSF-RJ under the action of the EL-Centro ground motion was analyzed. Under the action of ground motion of PGA $=0.07 \mathrm{~g}$, the hysteretic curves are linear. Hysteretic loops begin appearing because of the beam-column connections opening and the friction dampers dissipating energy under the action of ground motion of $\mathrm{PGA}=0.2 \mathrm{~g}$. Hysteretic loops have essentially formed under the action of ground motion of $\mathrm{PGA}=0.4 \mathrm{~g}$; in addition, the energy dissipated by the friction damper increased when compared with that under the action of ground motion of PGA $=0.2 \mathrm{~g}$. Hysteretic loops have completely formed under the action of ground motion of $\mathrm{PGA}=0.51 \mathrm{~g}$. 


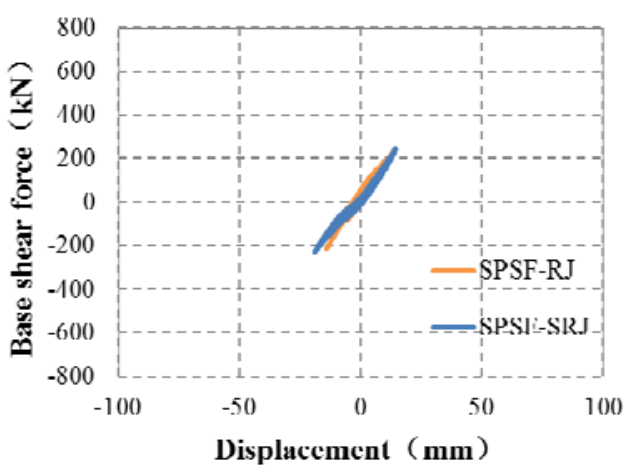

a) $\mathrm{PGA}=0.07 \mathrm{~g}$

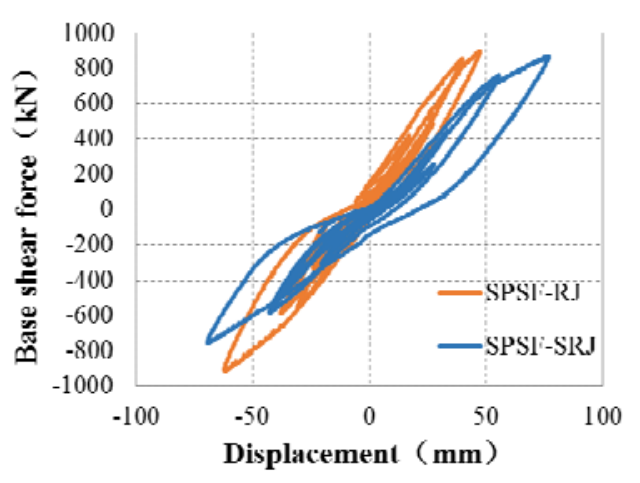

c) $\mathrm{PGA}=0.4 \mathrm{~g}$

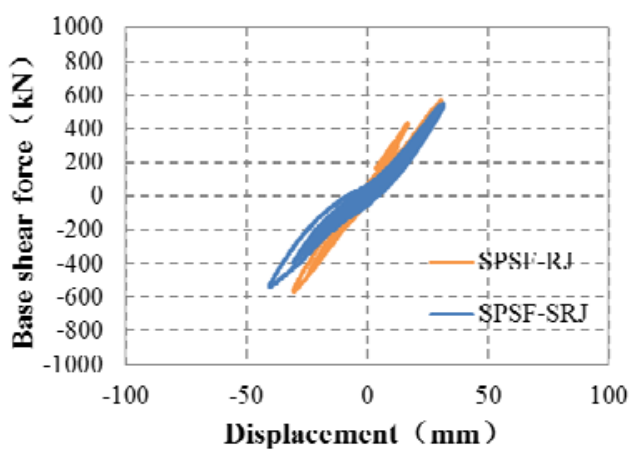

b) $P G A=0.2 \mathrm{~g}$

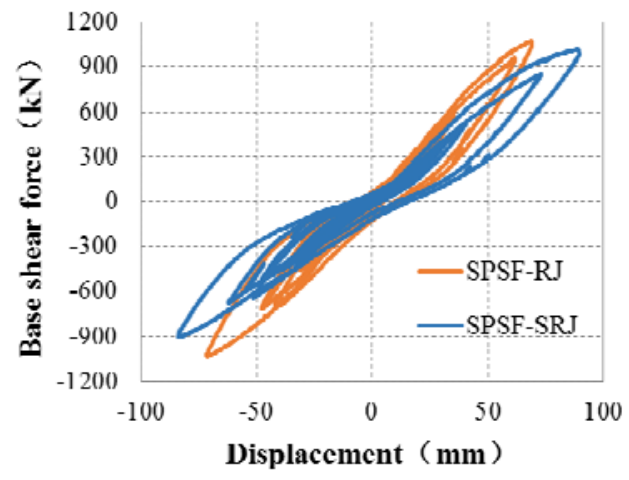

c) $\mathrm{PGA}=0.51 \mathrm{~g}$

Figure 18. Base Shear Force-displacement Response from EL-Centro

The effective energy dissipation coefficient $\left(\beta_{\mathrm{E}}\right)$ can be used to quantitatively analyze the hysteretic behavior and energy dissipation capability of the SPSF-SRJ and SPSF-RJ. The $\beta$ E refers to the ratio of the actual energy dissipation of a system to the energy dissipation for a bilinear elastic-plastic system with the same capacity. To enable a satisfactory response for the SC-MRF under seismic loading to be achieved, Seo and Sause [19] recommend that $\beta_{\mathrm{E}} \geq 0.25$.

Table 6 lists the $\beta_{\mathrm{E}}$ of the SPSF-SRJ and SPSF-RJ under the action of different earthquakes levels. When PGA is $0.07 \mathrm{~g}$, there is no energy dissipation, and the $\beta_{\mathrm{E}}$ are all zero. When PGA increases to $0.2 \mathrm{~g}$, the maximum $\beta_{\mathrm{E}}$ of SPSF-SRJ and SPSF-RJ are 0.288 and 0.209 . When PGA increases to $0.4 \mathrm{~g}$, the maximum $\beta$ E of SPSF-SRJ and SPSF-RJ are 0.349 and 0.314 . The $\beta_{\mathrm{E}}$ are close to or greater than 0.25 . When PGA increases to $0.51 \mathrm{~g}$, the maximum $\beta$ E of SPSF-SRJ and SPSF-RJ are 0.296 and 0.295 , respectively. The $\beta_{\mathrm{E}}$ are all greater than 0.25 . However, the $\beta$ E of SPSF-SRJ are always greater than that of SPSF-RJ.

Table 6. The Effective Energy Dissipation Ratios $(\beta \mathrm{E})$

\begin{tabular}{cccccc}
\hline \multicolumn{2}{c}{ Seismic events } & $0.07 \mathrm{~g}$ & $0.2 \mathrm{~g}$ & $0.4 \mathrm{~g}$ & $0.51 \mathrm{~g}$ \\
\hline \multirow{3}{*}{ SPSF-RJ } & Taft & 0 & 0 & 0.248 & 0.270 \\
& LOS000 & 0 & 0 & 0.264 & 0.282 \\
& EL-Centro & 0 & 0.209 & 0.314 & 0.295 \\
& Taft & 0 & 0 & 0.219 & 0.292 \\
SPSF-SRJ & LOS000 & 0 & 0.220 & 0.265 & 0.276 \\
& EL-Centro & 0 & 0.288 & 0.349 & 0.296 \\
\hline
\end{tabular}




\subsection{Analysis of Secant Stiffness}

The stiffness of a structure reflects the deformability of the structure. Due to the gap openings of the beam-column connections of the test frame, the stiffness of the test frame decreases with increasing number of test cycles and increasing deformation of the test frame during the test process; such a phenomenon is called the stiffness degradation. The secant stiffness $\left(K_{i}\right)$ is used to express the stiffness of the frame and is calculated using the following Eq. 1:

$$
K_{i}=\frac{\left|+F_{i}\right|+\left|-F_{i}\right|}{\left|+\Delta_{i}\right|+\left|-\Delta_{i}\right|}
$$

where $F_{i}$ represents the value of the force at the $i^{\text {th }}$ peak point; $\Delta_{i}$ represents the value of the displacement at the $i^{\text {th }}$ peak point.

Table 7 lists the secant stiffness of the SPSF-SRJ and SPSF-RJ. The stiffness of each structure exhibits a decreasing trend with increasing energy dissipated by the openings of the connections. The stiffness of the SPSF-RJ degrades from $19210 \mathrm{kN} / \mathrm{m} \quad(P G A=0.2 \mathrm{~g}$ ) to $15021 \mathrm{kN} / \mathrm{m}$ $(\mathrm{PGA}=0.51 \mathrm{~g})$, whereas the stiffness of the SPSF-SRJ degrades from $15455 \mathrm{kN} / \mathrm{m}(\mathrm{PGA}=0.2 \mathrm{~g})$ to $11119 \mathrm{kN} / \mathrm{m}(\mathrm{PGA}=0.51 \mathrm{~g})$. The stiffness of the SPSF-SRJ is always lower than that of the SPSF-RJ.

Table 7. Secant stiffness of structure $(\mathrm{kN} / \mathrm{m})$

\begin{tabular}{ccccc}
\hline \multicolumn{2}{c}{ Seismic events } & $0.2 \mathrm{~g}$ & $0.4 \mathrm{~g}$ & $0.51 \mathrm{~g}$ \\
\hline \multirow{3}{*}{ SPSF-RJ } & Taft & 18844 & 18694 & 17391 \\
& LOS000 & 19210 & 18596 & 16546 \\
& EL-Centro & 18687 & 17358 & 15021 \\
\multirow{3}{*}{ SPSF-SRJ } & Taft & 15455 & 13692 & 14020 \\
& LOS000 & 15190 & 13542 & 13294 \\
& EL-Centro & 15106 & 11146 & 11119 \\
\hline
\end{tabular}

\subsection{PT Force Analysis}

\subsubsection{PT force on the column}

Four prestressed strands were placed on one column and the total initial PT force was $756 \mathrm{kN}$ (axial compression ratio is about 0.2 ).During the loading process, the maximum vertical PT force ranged from $6 \mathrm{kN}$ at the peak ground acceleration of $0.07 \mathrm{~g}$ to $25 \mathrm{kN}$ at the peak ground acceleration of $0.51 \mathrm{~g}$; the axial force remained essentially stable, as shown in Figure 19. 


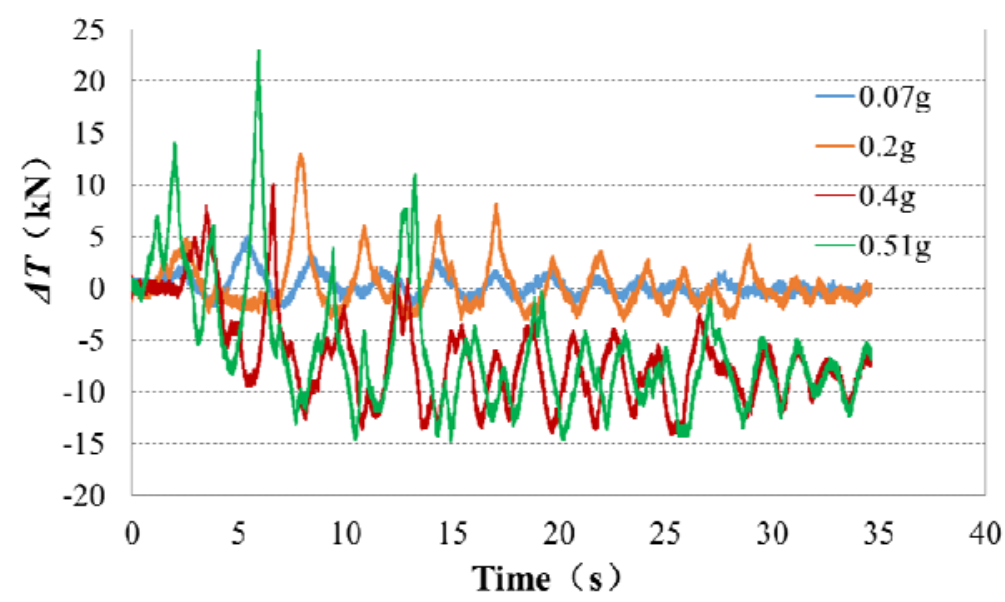

Figure 19. PT Force on the Column from EL-Centro

\subsubsection{PT force on the beam}

The SPSF-SRJ has a span of $6 \mathrm{~m}$. Each prestressed strand has an effective length of $5.06 \mathrm{~m}$. After the gap openings of the connections were formed, the PT force of each prestressed strand increased with the increasing length of the prestressed strand. The extension of each prestressed strand is related to the gap opening rotation of the connections on the east and west sides. Therefore, the curves of the relationships between the PT forces and mean gap opening rotations are plotted for analysis. Figure 20-22 shows the changes in the PT forces of the SPSF-SRJ and SPSF-RJ with the mean gap opening rotations when the SPSF-SRJ and SPSF-RJ are under the action of the EL-Centro ground motion of $\mathrm{PGA}=0.2 \mathrm{~g}, 0.4 \mathrm{~g}, 0.51 \mathrm{~g}$. The mean gap opening rotation is set as the abscissa, and $T / T_{\mathrm{u}}$ is set as the ordinate ( $T$ is the mean PT force during the test, $T_{\mathrm{u}}$ is the ultimate PT force, its value is $591 \mathrm{kN}$ which is obtained based on the material properties of the prestressed strand.), the PT force of the side strand is the mean PT force of strands 1, 4, 5, and 8; and the PT force of the middle strand is the mean PT force of strands 2,3,6, and 7; Take the side strands for an example. The side strands of the SPSF-RJ and SPSF-SRJ have initial PT forces of $148 \mathrm{kN}$ and 150 $\mathrm{kN}\left(0.25 T_{\mathrm{u}}\right)$, respectively, and maximum PT forces of $172 \mathrm{kN}$ and $178 \mathrm{kN}\left(0.30 T_{\mathrm{u}}\right)$, respectively. After the tests have terminated, the PT forces return to $148 \mathrm{kN}$ and $148 \mathrm{kN}\left(0.25 T_{\mathrm{u}}\right)$, respectively; thus, there is essentially no loss of the PT forces of the side strands.

As shown in Figure 21, when PGA increases to $0.4 \mathrm{~g}$, The prestressed strands of the SPSF-RJ and SPSF-SRJ have initial PT forces of $148 \mathrm{kN}\left(0.25 T_{\mathrm{u}}\right)$ and $160 \mathrm{kN}\left(0.27 T_{\mathrm{u}}\right)$, respectively, and maximum PT forces of $229 \mathrm{kN}\left(0.39 T_{\mathrm{u}}\right)$ and $245 \mathrm{kN}\left(0.42 T_{\mathrm{u}}\right)$, respectively. After the tests have terminated, the PT force of the SPSF-RJ and the SPSF-SRJ returned to $148 \mathrm{kN}\left(0.25 T_{\mathrm{u}}\right)$ and $153 \mathrm{kN}$ $\left(0.26 T_{\mathrm{u}}\right)$, respectively; thus, there are nearly no losses in the PT forces.

As shown in Figure 22, when PGA increases to $0.51 \mathrm{~g}$, The prestressed strands of the SPSF-RJ and SPSF-SRJ have initial PT forces of $141 \mathrm{kN}\left(0.24 T_{\mathrm{u}}\right)$ and $154 \mathrm{kN}\left(0.26 T_{\mathrm{u}}\right)$, respectively, and maximum PT forces of $254 \mathrm{kN}\left(0.43 T_{\mathrm{u}}\right)$ and $266 \mathrm{kN}\left(0.45 T_{\mathrm{u}}\right)$, respectively. After the tests have terminated, the PT force of the SPSF-RJ and the SPSF-SRJ returned to $141 \mathrm{kN}\left(0.24 T_{\mathrm{u}}\right)$ and $148 \mathrm{kN}$ $\left(0.25 T_{\mathrm{u}}\right)$, respectively; which indicates that the prestressed strands of the SPSF-SRJ, the performance of the anchorage device, and the prestress tensioning method are reliable, providing a good basis for the SPSF-SRJ to normally operate and shows that it can bear the impacts from relatively large, multiple aftershocks after the occurrence of rare and extremely rare earthquakes. 


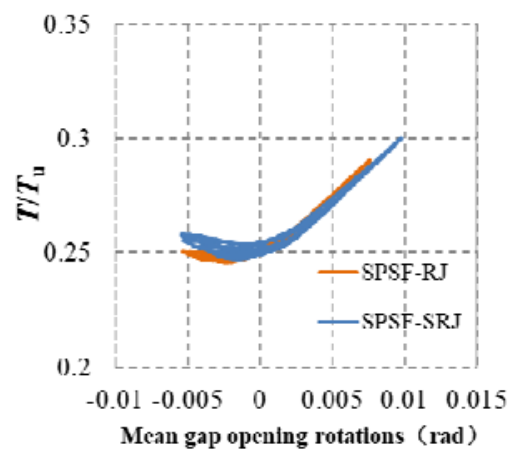

a) Side strand

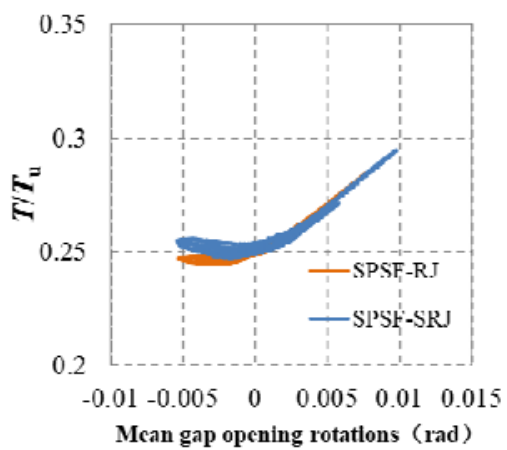

b) Middle strand

Figure 20. PT Force from EL-Centro(PGA=0.2g)

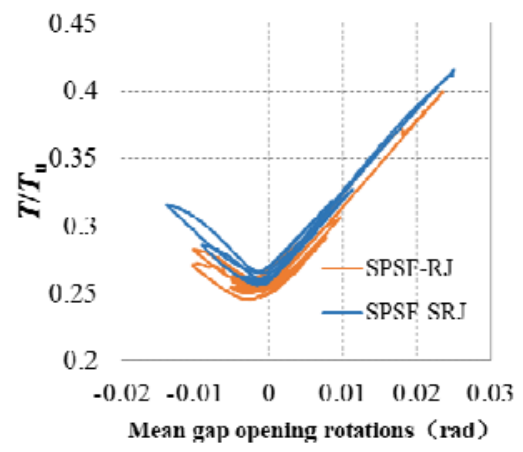

a) Side strand

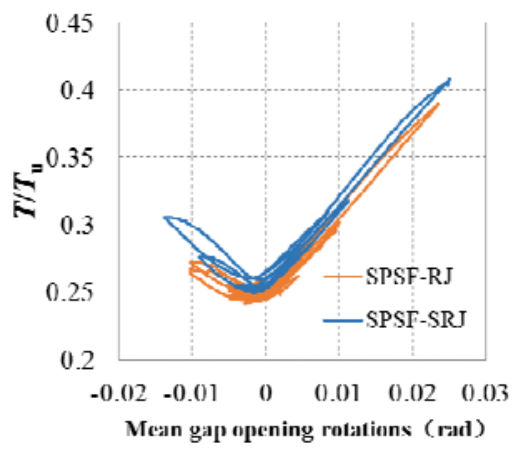

b) Middle strand

Figure 21. PT Force from EL-Centro $(\mathrm{PGA}=0.4 \mathrm{~g})$

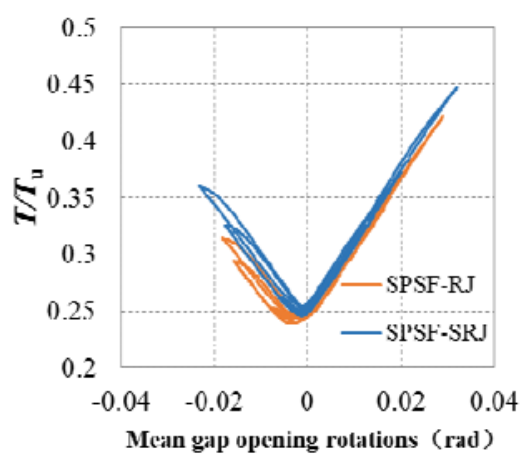

a) Side cables

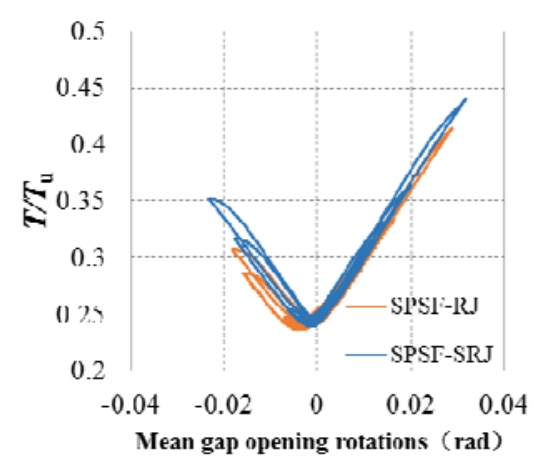

b) Middle cables

Figure 22. PT Force from EL-Centro $(P G A=0.51 \mathrm{~g})$

\subsection{Analysis of Strain}

Table 10 lists the maximum values of the strain at different parts of the SPSF-SRJ and SPSF-RJ when the SPSF-SRJ and SPSF-RJ were under the action of earthquakes with different degrees. Under the action of ground motion of $\mathrm{PGA}=0.07 \mathrm{~g}$, no plastic development occurred in the entire SPSF-SRJ and SPSF-RJ. Under the action of ground motion of $\mathrm{PGA}=0.2 \mathrm{~g}$, each part of the SPSF-SRJ and SPSF-RJ was still under an elastic state; the values of the strain at the flange of the short beam, flange of the long beam, flange in the connection region, and the web plate of the SPSF-SRJ were slightly greater than those of the SPSF-RJ; in addition, the values of the strain at the flange and web plate of the column base of the SPSF-SRJ were far smaller than those of the SPSF-RJ. The performance-based goal of "no structural damage" was realized in the SPSF-SRJ when the SPSF-SRJ was under the action of a frequent earthquake as well as under the action of a design earthquake. 
Under the action of ground motion when PGA is $0.4 \mathrm{~g}$, the flange of the long beam and web plate in the connection region of the SPSF-RJ were under the elastic state; the flange of the short beam, flange in the connection region, flange and web of the column base of the SPSF-RJ all began to yield; however, the values of the strain at these parts did not exceed twice the value of the yield $\operatorname{strain}\left(2 \varepsilon_{y}\right)$; the value of the plastic strain at the reinforcing plate near the vertical plate on the long beam flange exceeded $2 \varepsilon_{y}$. During the test, the flange of the short beam, reinforcing plate, flange and web in the connection region of the SPSF-SRJ entered the plastic state; the values of the strain at the flange of the short beam, reinforcing plate near the vertical plate on the long beam, and web plate in the connection region of the SPSF-SRJ are larger than those of the SPSF-RJ and exceeded $2 \varepsilon_{y}$. Figures 23 and 24 show the strain-time history curves of the flanges of the short beams and web plates in the connection regions of the SPSF-SRJ and SPSF-RJ. The value of the strain at the flange in the connection region of the SPSF-SRJ did not exceed $2 \varepsilon_{y}$ and was smaller than that of the SPSF-RJ. The flange of the long beam, flange and web of the column base of the SPSF-SRJ were all under the plastic state, the strain-time history curves of the flanges of the column bases of the SPSF-SRJ and SPSF-RJ are shown in Figure 25.

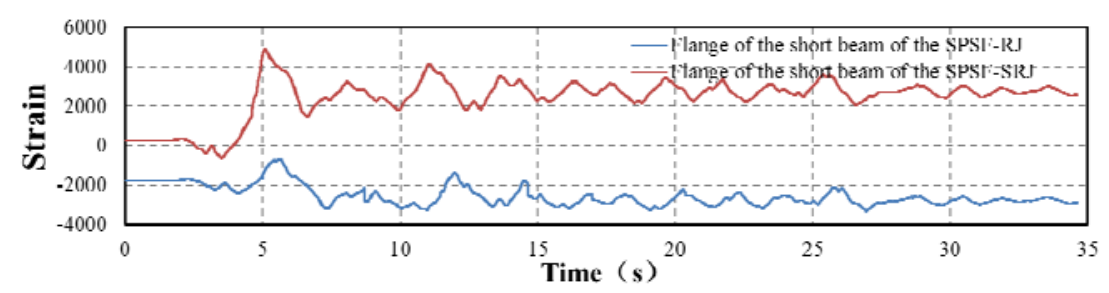

Figure 23. Strain-time History Curves of the Flanges of the Short Beams of the SPSF-SRJ and SPSF-RJ under the Action of the EL-Centro $(\mathrm{PGA}=0.4 \mathrm{~g})$

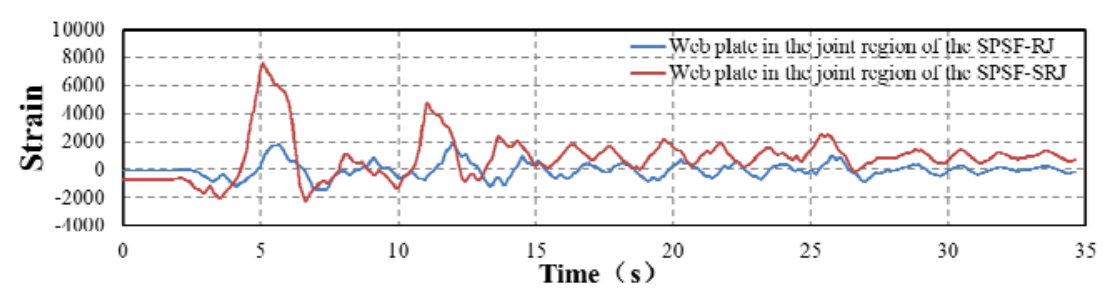

Figure 24. Strain-time History Curves of the Web Plates in the Connection Regions of the SPSF-SRJ and SPSF-RJ under the Action of the EL-Centro （PGA=0.4g）

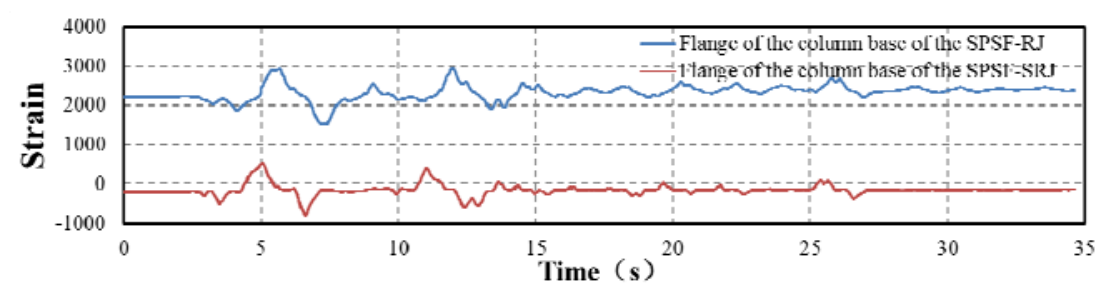

Figure 25. Strain-time History Curves of the Flanges of the Column Base of the SPSF-SRJ and SPSF-RJ under the Action of the EL-Centro $\quad(\mathrm{PGA}=0.4 \mathrm{~g})$

Under the action of ground motion of PGA $=0.51 \mathrm{~g}$, the plasticity of each part of the SPSF-SRJ and SPSF-RJ continues to develop. In addition to the flange of the long beam of the SPSF-RJ being under the elastic state, all other parts of the SPSF-RJ had entered the plastic state; the strain at the location where the reinforcing plate is near the vertical plate on the long beam had a maximum value of $7273 \mu \varepsilon$; the maximum yield strain at the flange of the short beam had a value as high as 
$4507 \mu \varepsilon$. During the test, the flange of the short beam, reinforcing plate, flange and web in the connection region of the SPSF-SRJ had entered the plastic state; the flange of the long beam had just entered the plastic state; the strain at the flange in the connection region did not exceed $2 \varepsilon_{y}$. Figures 26 and 27 show the strain-time histories of the flange of the short beams and the web plates in the connection regions of the SPSF-SRJ and SPSF-RJ. However, the flange and web of the column base of the SPSF-SRJ were all under the elastic state. Figure 28 gives the strain-time histories of the flanges of the column bases of the SPSF-SRJ and SPSF-RJ. The performance-based goal of "only relatively small damage occurs and the structure can still normally operate" was realized in the SPSF-SRJ under the action of a rare earthquake as well as a rare 8.5-degree earthquake.

Hence, the use of semi-rigid joints to connect the column base of a self-centering steel frame can effectively protect the column base; however, the plasticity of the flange of the short beam and web plate of the column in the connection region will increase. The web plate in the connection region can be strengthened via a steel plate in future designs to eliminate or reduce the damage on the entire column; only the steel beam would require repairs after an earthquake, significantly reducing the post-earthquake repair cost.

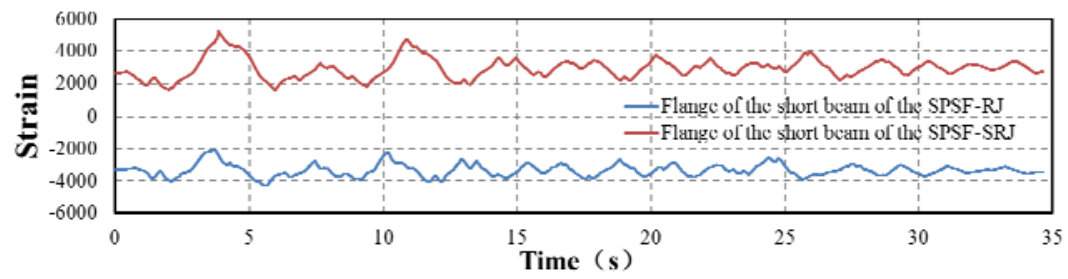

Figure 26. Strain-time History Curves of the Flanges of the Short Beams of the SPSF-SRJ and SPSF-RJ when the SPSF-SRJ and SPSF-RJ are under the Action of the EL-Centro (PGA=0.51g)

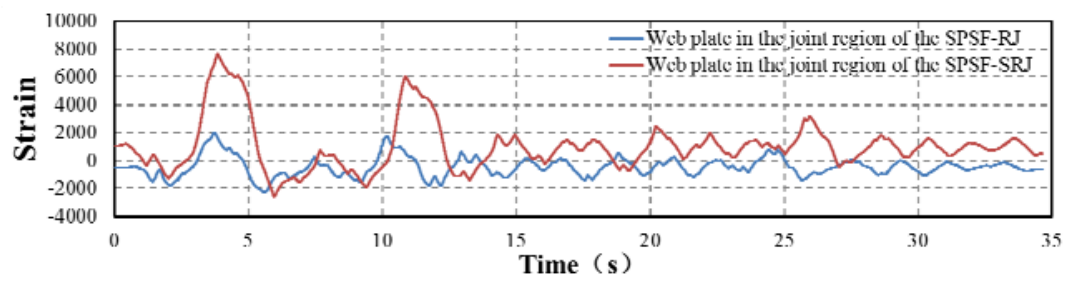

Figure 27. Strain-time History Curves of the Web Plates in the Connection Regions of the SPSF-SRJ and SPSF-RJ when the SPSF-SRJ and SPSF-RJ are under the Action of the EL-Centro $\quad(\mathrm{PGA}=0.51 \mathrm{~g})$

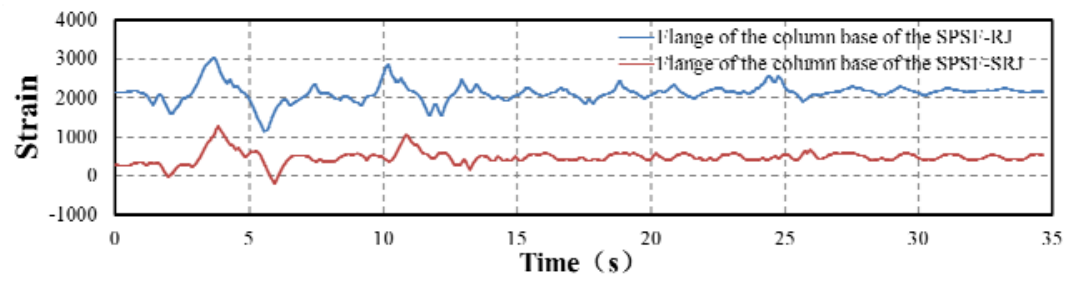

Figure 28. Strain-time History Curves of the Flanges of the Column base of the SPSF-SRJ and SPSF-RJ when the SPSF-SRJ and SPSF-RJ are under the Action of the EL-Centro （PGA=0.51g） 
Table10. Maximum Values of the Strain at Different Parts of Structure

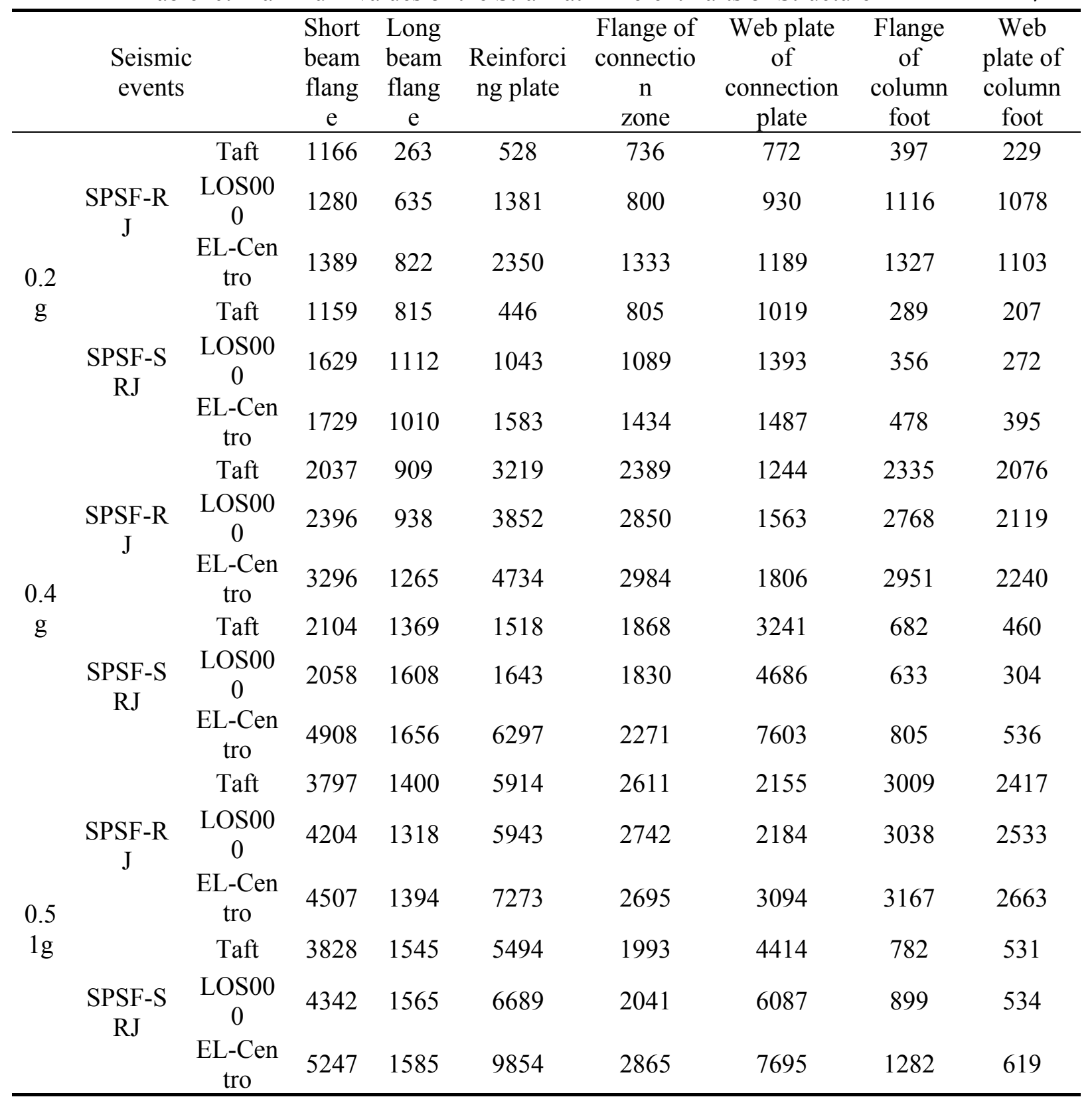

\section{CONCLUSIONS}

In the present study, a $3 \times 5$ bays 4 -story SPSF-SRJ prototype structure was scaled down by $75 \%$. A pseudo-dynamic test was performed on the planar frame sub-structure under the action of different levels of earthquake degrees. In addition, the pseudo-dynamic test results of the SPSF-SRJ are compared with those of the SPSF-RJ that were previously obtained in our research group. The following conclusions were obtained: 
(1) The performance-based design goal - "no opening and no damage occurs during frequent earthquakes; openings are formed to dissipate energy, and no damage occurs to the main structure during design earthquakes; only extremely small structural damage occurs, and the structure can still normally operate during rare and extremely rare earthquakes" - was realized in the SPSF-SRJ.

(2) The stiffness of the SPSF-SRJ was lower than that of the SPSF-RJ. Therefore, the displacement responses and openings of the connections of the SPSF-SRJ were greater than those of the SPSF-RJ. The base shear force of the SPSF-SRJ was smaller than that of the SPSF-RJ.

(3) Similar to the SPSF-RJ, the SPSF-SRJ also exhibited a good opening/closing mechanism. The SPSF-SRJ had a double-flag-shaped hysteretic curve. The SPSF-SRJ exhibited relatively good post-earthquake self-centering and energy dissipation capabilities. With increasing seismic acceleration peak values, the energy dissipation coefficient generally exhibited an increasing trend, and the energy dissipation capability of the SPSF-SRJ increased to a certain degree.

(4) After the test, there were relatively small losses in the PT forces of the prestressed strands, indicating that the prestressed strands of the SPSF-SRJ, performance of the anchorage device, and prestress tensioning method are reliable, which provides a good basis for the SPSF-SRJ to normally operate and bear impacts from relatively large, multiple aftershocks after the occurrence of rare and extremely rare earthquakes.

(5) There is a relatively large difference in the development of plasticity between the SPSF-SRJ and SPSF-RJ. The reinforcing plate of the SPSF-RJ enters the plastic state first when the SPSF-RJ is under the action of a design earthquake; afterwards, the flange of the short beam, flange and web of the column base, and web and flange in the connection region, connection of the SPSF-RJ enter the plastic state successively with increasing earthquake degree; under the protection of the reinforcing plate, the flange of the long beam maintains its elasticity throughout the process. Different from the SPSF-RJ, the SPSF-SRJ maintains its elastic state when the SPSF-SRJ is under the action of an 8-degree frequent earthquake as well as under the action of an 8-degree design earthquake. Under the action of an 8-degreerare earthquake, the web plate in the beam-column connection region of the SPSF-SRJ enters the plastic state first, after which, the reinforcing plate, flange of the short beam, and flange in the connection region enter the plastic state successively. Under the action of an 8.5-degree rare earthquake, the plasticity of the each part of the SPSF-SRJ continues to develop; however, the flange of the column base, web plate of the column base, and flange of the long beam all still maintain their elasticity.

(6) Overall, using semi-rigid joints to connect the column base of a self-centering steel frame effectively protects the column base and allows the column base to maintain its elastic state; however, the plasticity of the web plate of the column in the joint region of the SPSF-SRJ will increase when compared with that of the SPSF-RJ. The column joint region should be strengthened in future designs to eliminate or reduce damage to the column; only the steel beam would require repairs after an earthquake, significantly reducing post-earthquake repair costs.

\section{ACKNOWLEDGMENTS}

The research reported herein is supported by the National Natural Science Foundation of China under Grant No. 51278027, the Key Project of Beijing Natural Science Foundation under Grant No.8131002 and the Project of Constructing Beijing Energy Saving and Emission Reduction Technology Collaborative Innovation Center. 


\section{REFERENCES}

[1] Rojas, P., Ricles, J. M. and Sause, R., "Seismic Performance of Post-tensioned Steel Moment Resisting Frames With Friction Devices", Journal Structural Engineering, 2005, Vol. 131, No. 4, pp. 529-540.

[2] Lin, Y. C., Ricles, J. M. and Sause, R., "Earthquake Simulations on Self-centering Steel Moment Resisting Frame with Web Friction Devices", Structures Congress 2009, Reston Virginia: American Society of Civil Engineers, 2009.

[3] Ricles, J. M., Sause, R., Lin, Y. and Seo, C., "Self-centering Moment Connections for Damage-free Seismic Response of Steel MRFs", Structures Congress 2010, Orlando, Reston Virginia: American Society of Civil Engineers, 2010.

[4] Lin, Y. C., Sause, R. and Ricles, J. M., "Seismic Performance of Steel Self-centering, Moment-resisting Frame: Hybrid Simulations under Design Basis Earthquake”, Journal of Structural Engineering, 2013, Vol. 139, No. 5, pp. 1823-1832.

[5] Lin, Y. C., Sause, R. and Ricles, J. M., "Seismic Performance of a Large-scale Steel Self-centering Moment-resisting Frame : MCE Hybrid Simulations and Quasi-static Pushover Tests", Journal of Structural Engineering, 2013, Vol. 139, No. 7, pp. 1227-1236.

[6] Zhang, Y. X., Ye, J. J., Yang, F. and Chen, Y. Y., "Dynamic Behavior and Time-history Analysis of Integral Self-centering Moment Resisting Frames", China Civil Engineering Journal, 2015, Vol. 48, No. 7, pp. 30-40. (in Chinese)

[7] Zhang, Y. X., Zhang, A. L. and Sun, W.L., "Behavior Study of Self-centering Beam-column Connections in Resilient Steel Frames after Earthquake", Industrial Construction, 2014, Vol. 44, No. 502, pp. 160-167. (in Chinese)

[8] Chi, H., Liu, J. and Garlock M., "Design and Analytical Validation of Post-tensioned Column Bases", Vancouver, British Columbia, Canada: Structures 2008: Crossing Borders 2008, ASCE.

[9] Chi, H., "Development of Post-tensioned Column Base Connection for Self-centering Seismic Resistant Steel Frame", West Lafayette, Indiana: Purdue University, 2009.

[10] Georgios, A., Gary, F, and Andre, F. "Computational Framework for Automated Seismic Design of Steel Frames with Self-Centering Connections", Journal of Computing in Civil Engineering, 2014, Vol. 28, pp.170-181.

[11] Matthew, R. and Xiang, M. "Design Concepts for Controlled Rocking of Self-Centering Steel-Braced Frames", Struct. Eng., 2014, Vol. 140, pp. 1-11.

[12] Gandomi, A. and Roke, D., "Seismic Response Prediction of Self-Centering Concentrically Braced Frames Using Genetic Programming”, Structures Congress. 2014, pp.1221-1232.

[13] Darling, S., Eatherton, M. and Maurya, A., "Self-Centering Beams for Seismically Resilient Moment Frames" Structures Congress, 2013, pp.1701-1712.

[14] Pacific Earthquake Engineering Research Center. "Guidelines for Performance-based Seismic Design of Tall Buildings", California: University of California, Berkeley, 2010.

[15] Structural Engineers Association of California, "2012 IBC SEAOC Structural/seismic Design Manual", Vol. 4, California, 2012.

[16] American Institute of Steel Construction, "Seismic Provisions for Structural Steel Buildings", Chicago: AISC Committee on Specifications, 2010.

[17] American Institute of Steel Construction, "Prequalified Connections for Special and Intermediate Steel Moment Frames for Seismic Applications", Chicago: AISC Board of Directors, 2010.

[18] GB 50011-2010, "Code for Seismic Design of Buildings", Beijing: China Architecture \& Building Press, 2010 (in Chinese)

[19] Seo, C. Y., and Sause, R., "Ductility Demands on Self-centering Systems under Earthquake Loading.” ACI Struct. J., 2005, Vol. 102, No. 2, pp. 275-285. 